\title{
Synovial fluid cells in Reiter's syndrome
}

\author{
DAN NORDSTRÖM ${ }^{1}$ YRJÖ T KONTTINEN,${ }^{1}$ VILLE BERGROTH, ${ }^{1}$ AND \\ MARJATTA LEIRISALO-REPO
}

From the ${ }^{1}$ Fourth Department of Medicine, and the ${ }^{2}$ Second Department of Medicine, Helsinki University $\widehat{\Phi}^{\circ}$ Central Hospital, Helsinki, Finland

SUMMARY Synovial fluid cells in Reiter's syndrome were studied by cell subset specific monoclonal antibodies and avidin-biotin-peroxidase complex staining. Mean leucocyte coun was $9842 / \mathrm{mm}^{3}\left(9 \cdot 842 \times 10^{9} / \mathrm{l}\right)$, and $71 \%$ of all cells were polymorphonuclear leucocytes: $26 \pm 11(\mathrm{SEM}) \%$ and $47 \pm 5 \%$ of all mononuclear cells in synovial fluid were $\mathrm{M}^{+}$monocytes and ${ }^{+}$ $\mathrm{Ia}^{+}$cells, respectively. $\mathrm{T}^{+} 1^{+} \mathrm{T}$ lymphocyte was the predominant synovial fluid mononuclear cell $\vec{N}$ $(61 \pm 8 \%)$ but, in contrast to the inflammatory joint effusions in rheumatoid arthritis, $\mathrm{T}^{+}$cells clearly outnumbered $\mathrm{T} 8^{+}$cells in Reiter's syndrome. Thus the synovial fluid in Reiter's syndromeo contains the immunocompetent and accessory cells required for immune response, which in face is activated as suggested by lymphocyte Ia expression. Furthermore, in contrast with rheumatoid arthritis inducer/helper cells with T4 phenotype seem to be involved preferentially in the locap pathogenetic mechanisms in Reiter's syndrome.

Key words: monoclonal antibodies, immunohistochemistry, reactive arthritis.

Diagnosis of Reiter's syndrome is based on a constellation of clinical findings, which sometimes includes the complete, classic triad of arthritis, urethritis, and conjunctivitis. ${ }^{12}$ Although the disease mechanism is unknown, we now recognise several different infective agents ${ }^{13}$ and a specific genetic background. ${ }^{45}$ Reiter's syndrome is not an infectious arthritis, because synovial fluid microbial cultures of the relevant micro-organisms are, according to disease definition, negative. ${ }^{6}$ Activation and/or abnormalities in $B$ and $T$ cell mediated functions have been reported in Reiter's syndrome ${ }^{7-11}$ and immunological mechanisms may be responsible for the transition of the infectious enteric or venereal action into a reactive complication located in the joints and enthesis. ${ }^{12}$ However, all the above-mentioned immunological studies ${ }^{7-11}$ were performed with samples derived from peripheral blood. Changes in the diseased joints are largely unknown. This prompted us to study the occurrence in the synovial fluid of cells participating in inflammatory and immune responses in Reiter's syndrome.

Accepted for publication 16 May 1985.

Correspondence to $\mathrm{Dr}$ Dan Nordström, Helsinki University Central Hospital, Fourth Department of Medicine, Division of Rheumatic Diseases, Unioninkatu 38, 00170 Helsinki 17, Finland.

\section{Patients and methods}

PATIENTS

All five patients studied fulfilled the diagnostic criteria of the American Rheumatism Association for definite Reiter's syndrome ${ }^{2}$ (for clinical data se 3 Table 1). They all had seronegative asymmetrie arthropathy of more than one month's duration and. all except one were HLA-B27 positive. Synoviap fluid specimens were collected from the knee joinf by needle aspiration into heparinised tubes an ${ }_{B}$ incubated with hyaluronidase for $30 \mathrm{~min}$ at $37^{\circ} \mathrm{C} \%$ Five patients with definite or classical rheumatoiof arthritis ${ }^{13}$ were studied for comparison.

I M M U NOH IS T O C H E M IS TR Y

Cytocentrifuge preparations obtained by spinning $1.5 \times 10^{5}$ cells per slide were fixed in cold acetone for five minutes and washed with phosphate-buffere尔 saline (PBS; pH 7.3, 0.1 M). The cytospin prepara $\omega$ tions were stained by the avidin-biotin-peroxidase complex (ABC) method introduced by Hsu al. ${ }^{14} 15$ Briefly, the endogenous peroxidase activity was blocked with $0.3 \% \mathrm{H}_{2} \mathrm{O}_{2}$ for 20 minutes. The slides were washed in PBS and then treated with: $(a)$ mouse monoclonal antibody, $(b)$ biotinylated horse 
Table 1 Clinical data on the patients

\begin{tabular}{|c|c|c|c|c|c|c|c|c|c|c|}
\hline \multirow[t]{2}{*}{$\begin{array}{l}\text { Patient } \\
\text { No }\end{array}$} & \multirow[t]{2}{*}{$\begin{array}{l}\text { Age } \\
\text { (years) }\end{array}$} & \multirow[t]{2}{*}{ Sex } & \multirow{2}{*}{$\begin{array}{l}\text { Duration of } \\
\text { the disease } \\
\text { (months) }\end{array}$} & \multirow[t]{2}{*}{$B 27$} & \multirow[t]{2}{*}{$\begin{array}{l}\text { Urethritis/ } \\
\text { cervicitis }\end{array}$} & \multirow[t]{2}{*}{ Dysentery } & \multirow[t]{2}{*}{ Arthritis } & \multicolumn{3}{|c|}{$\begin{array}{l}\text { Differential counting } \\
\text { of synovial fluid cells }\end{array}$} \\
\hline & & & & & & & & $\begin{array}{l}\text { leucocytes/ } \\
\mathrm{mm}^{3 *}\end{array}$ & $P M N(\%) \dagger$ & $M N(\%)+$ \\
\hline 1 & 35 & Male & 20 & + & - & $\begin{array}{l}+ \\
\text { (yersinia) }\end{array}$ & + & 11000 & 78 & 22 \\
\hline 2 & 29 & Male & 10 & + & $\begin{array}{l}+ \\
\text { (chlamydia) }\end{array}$ & - & + & 20270 & 30 & 70 \\
\hline 3 & 36 & Male & 2 & - & - & - & + & 11200 & 88 & 12 \\
\hline 4 & 39 & Male & 2 & + & $\begin{array}{l}+ \\
\text { (gonorrhoca) }\end{array}$ & - & + & 4230 & 82 & 18 \\
\hline 5 & 36 & Female & 24 & + & + & - & + & 2510 & 79 & 21 \\
\hline
\end{tabular}

* SI conversion: leucocytes $/ \mathrm{mm}^{3} \times 10^{6}=$ leucocytes $/$.

$\dagger \mathrm{PMN}=$ polymorphonuclear cells; $\mathrm{MN}=$ mononuclear cells.

antimouse antibody, and (c) avidin-biotin-peroxidase complex. The ABC kit was purchased from Vector Laboratories (Burlingame, California, USA). Finally, the peroxidase binding sites were shown with diaminobenzidine tetrahydrochloride (DAB; Sigma Chemical Co., St Louis, Missouri, USA), $50 \mathrm{mg} / 150 \mathrm{ml}(333 \mathrm{mg} / \mathrm{l}) \mathrm{PBS}$, and $0.003 \%$ $\mathrm{H}_{2} \mathrm{O}_{2}$ for five minutes. Between each step the slides were washed twice in PBS for five minutes. After the DAB reaction the slides were washed, counterstained with haematoxylin, and mounted. The following monoclonal antibodies were used in this study: OKT11, OKT4, OKT8, OKM1, OKIa (Ortho Diagnostic Systems İnc., Raritan, New Jersey, USA), and pan-B (Dakopatts, Copenhagen, Denmark).

To test the specificity of immunohistochemical staining the following controls were set up: $(a)$ omission of the primary monoclonal antibodies from the staining sequence, and $(b)$ use of inappropriate antibodies in the second stage (e.g., biotinylated goat antirabbit $\operatorname{IgG}$ ). The slides were also stained for endogenous peroxidase by the DAB reaction only.

EVALUATION OF THE RESULTS

Endogenous peroxidase activity was destroyed by $\mathrm{H}_{2} \mathrm{O}_{2}$ pretreatment; exogenous peroxidase-positive, specifically stained cells were brown and thus readily distinguishable under the light microscope. The standard error of the mean (SEM) was used to express dispersion of the data. The significance of differences between mean values was tested with Student's $t$ test.

\section{Results}

The percentages of various cell subpopulations in synovial fluid in Reiter's syndrome compared with rheumatoid arthritis are given in Table 2. Most of the synovial fluid inflammatory mononuclear cells were $\mathrm{T} 11^{+} \mathrm{T}$ lymphocytes $(61 \pm 8(\mathrm{SEM}) \%)$ or $\mathrm{M}^{+}$ monocytes $(26 \pm 11 \%)$ (Fig. 1), whereas there were few pan- $B^{+} B$ lymphocytes $(1 \pm 0 \cdot 5 \%)$. In contrast

Table 2 Various cell subsets as a percentage of all mononuclear cells in synovial fluid in Reiter's syndrome compared with rheumatoid arthritis*

\begin{tabular}{|c|c|c|c|c|c|}
\hline \multirow[t]{2}{*}{ Disease } & \multicolumn{5}{|c|}{ Inflammatory cell subsets (\%) } \\
\hline & $T 4$ & $T 8$ & $B$ & $M I$ & $l a$ \\
\hline $\begin{array}{l}\text { Reiter's syndrome } \\
\text { Rheumatoid arthritis (RA) }\end{array}$ & $\begin{array}{l}35 \pm 11 \\
27 \pm 6\end{array}$ & $\begin{array}{l}24 \pm 7 \\
55 \pm 5\end{array}$ & $\begin{array}{l}1 \pm 0 \cdot 5 \\
3 \pm 0 \cdot 8\end{array}$ & $\begin{array}{l}26 \pm 11 \\
12 \pm 3\end{array}$ & $\begin{array}{l}47 \pm 5 \\
54 \pm 8\end{array}$ \\
\hline $\mathrm{p}$ value & $\mathrm{p}>0.05$ & $\mathrm{p}<0 \cdot 02$ & $p>0.05$ & $p>0.05$ & $\mathrm{p}>0.05$ \\
\hline
\end{tabular}

\footnotetext{
* Values are mean \pm SEM
} 
with the inflammatory joint effusions in rheumatoid arthritis $\mathrm{T}^{+}$cells (Fig. 2 ) clearly outnumbered $\mathrm{T} 8^{+}$ cells (Fig. 3 ) in four patients with Reiter's syndrome (Table 3). The proportion of $\mathrm{Ia}^{+}$synovial fluid

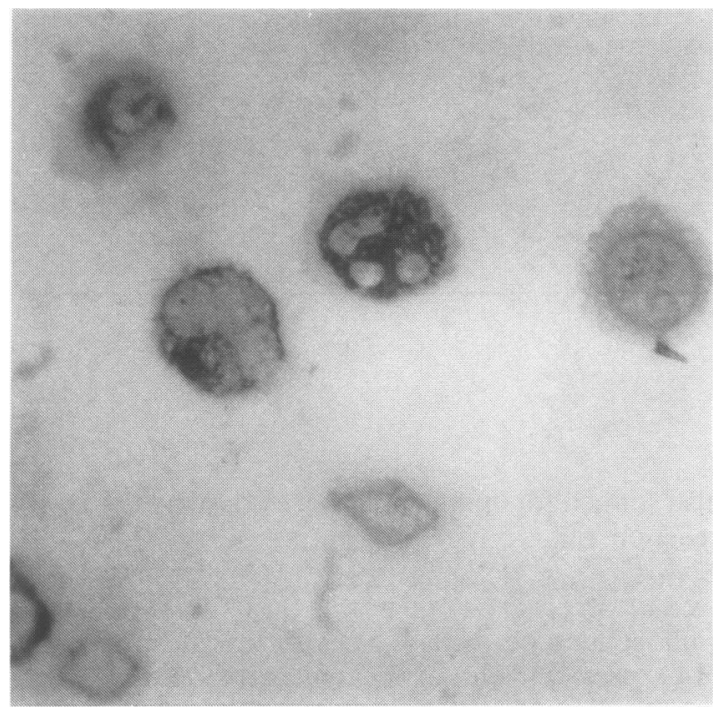

Fig. 1 Synovial fluid cells in Reiter's syndrome stained for $M 1$ by the avidin-biotin-peroxidase complex $(A B C)$ method. The peroxidase staining is visible in mononuclear phagocytes and polymorphonuclear leucocytes. $(\times 1000)$.

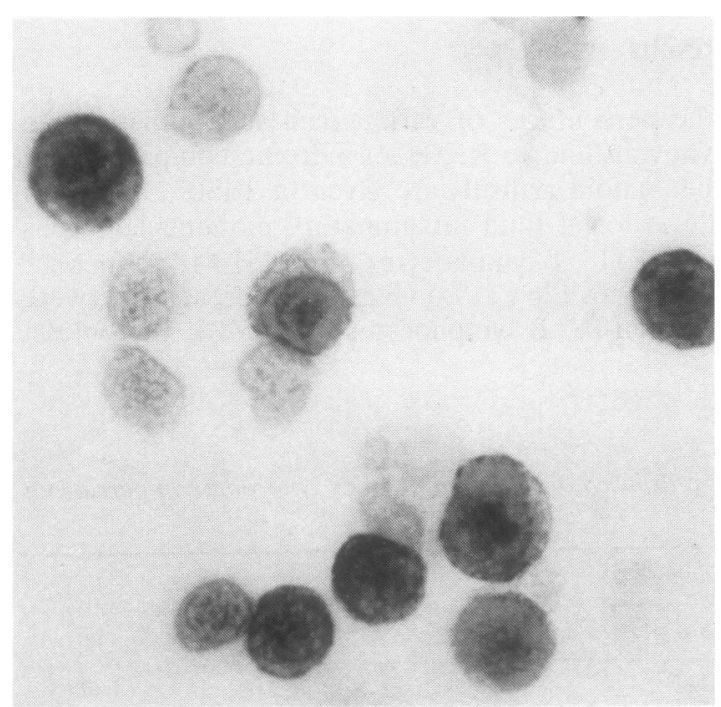

Fig. 2 Synovial fluid cells in Reiter's syndrome stained for T4 by the ABC method. The majority of lymphocytes display positive peroxidase staining. $(\times 1000)$. mononuclear cells was $47 \pm 5 \%$ in Reiter's syndrome (Fig. 4) and thus higher than the added proportion of monocytes and B lymphocytes. The staining controls were negative.

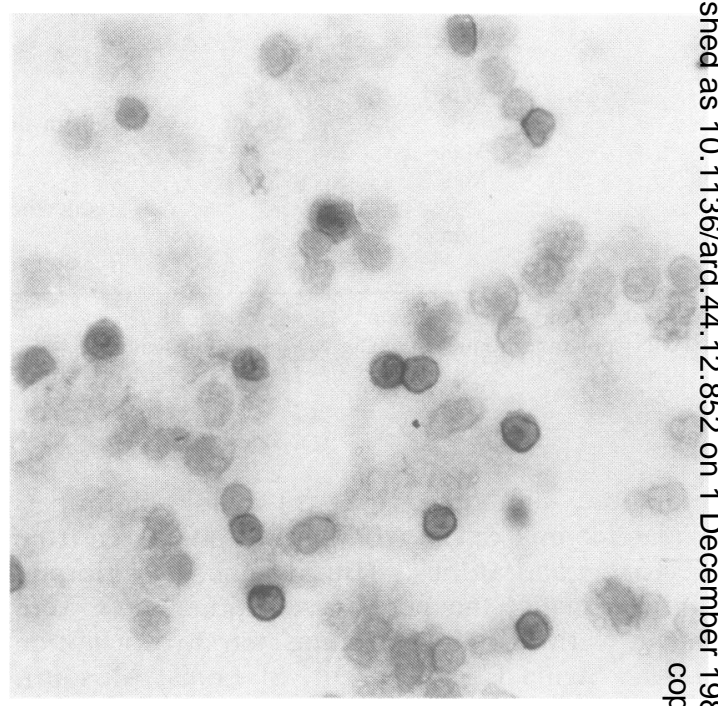

Fig. 3 Synovial fluid cells in Reiter's syndrome stained fọ $T 8$ by the $A B C$ method. $\mathrm{T}^{+}$suppressor/cytotoxic cells clearly visible. $(\times 400)$.

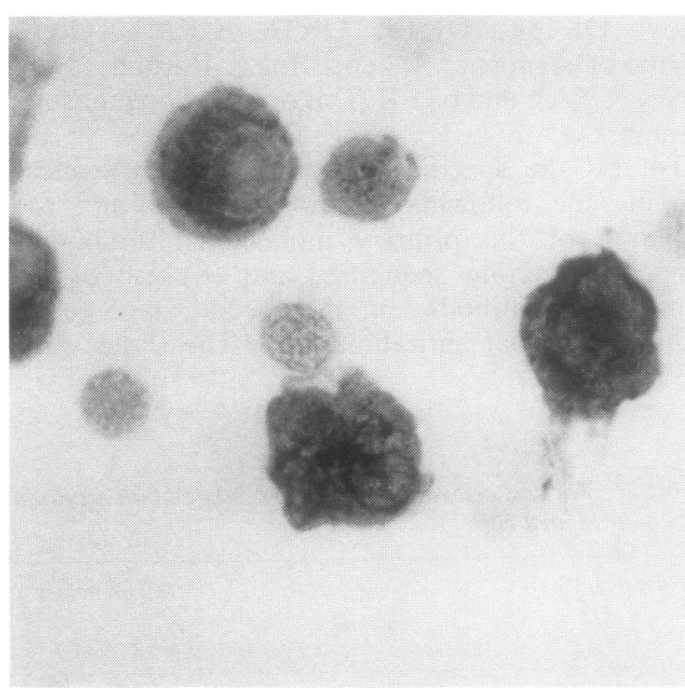

Fig. 4 Synovial fluid cells in Reiter's syndrome stained fo Ia by the ABC method. Most of the mononuclear phagocytes, $B$ lymphocytes, and activated Tlymphocytes display la marker. $(\times 1000)$. 
Table 3 Various cell subsets as actual numbers of cells $/ \mathrm{mm}^{3 *}$ and T4:T8 ratios for each patient

\begin{tabular}{|c|c|c|c|c|c|c|c|}
\hline \multirow[t]{2}{*}{ Disease } & \multirow{2}{*}{$\begin{array}{l}\text { Patient } \\
\text { No }\end{array}$} & \multicolumn{5}{|c|}{ Inflammatory cell subset } & \multirow{2}{*}{$\begin{array}{l}T 4: T 8 \\
\text { ratio }\end{array}$} \\
\hline & & $T 4$ & $T 8$ & $B$ & MI & $I a$ & \\
\hline \multirow[t]{5}{*}{ Reiter's syndrome } & 1 & 1355 & 895 & 73 & 169 & 1089 & 1.5 \\
\hline & 2 & 1703 & 6385 & 114 & 1845 & 4966 & $0 \cdot 3$ \\
\hline & 3 & 349 & 108 & 16 & 860 & 564 & $3 \cdot 2$ \\
\hline & 4 & 137 & 114 & 5 & 266 & 495 & $1 \cdot 2$ \\
\hline & 5 & 343 & 79 & 3 & 69 & 264 & $4 \cdot 3$ \\
\hline \multirow[t]{5}{*}{ RA } & 6 & 583 & 826 & 65 & 178 & 1004 & $0 \cdot 7$ \\
\hline & 7 & 1200 & 1720 & 40 & 840 & 2320 & $0 \cdot 7$ \\
\hline & 8 & 806 & 7258 & 504 & 605 & 4536 & $0 \cdot 1$ \\
\hline & 9 & 1488 & 2195 & 37 & 223 & 1711 & 0.7 \\
\hline & 10 & 1070 & 2548 & 102 & 764 & 3007 & 0.4 \\
\hline
\end{tabular}

* SI conversion: cells $/ \mathrm{mm}^{3} \times 10^{6}=$ cells $/ 1$.

\section{Discussion}

The cellular infiltrate in the early stages of Reiter's syndrome consists of neutrophilic polymorphonuclear leucocytes, lymphocytes, and plasma cells. ${ }^{16}$ In chronic Reiter's syndrome lymphocytes and plasma cells abound but there is no mention of mononuclea: phagocytes. ${ }^{16}$ However, by histochemical and immunohistochemical methods we have observed that mononuclear phagocytes are an important cell subpopulation in the inflammatory synovial membrane in acute and chronic rheumatoid arthritis. ${ }^{17} 18$ The frequent occurrence of $\mathrm{M}^{+}$monocytes and interleukin- $1^{19}$ suggests an active role for these cells in the local pathogenetic mechanisms in Reiter's syndrome, too.

$\mathrm{T}$ lymphocyte is the predominant mononuclear cell in joint effusions, not only in rheumatoid arthritis but also in ankylosing spondylitis, juvenile arthritis, and psoriatic arthropathy. ${ }^{20}$ Our study shows conclusively that this is also the case in Reiter's syndrome: sheep red blood cell receptor positive $\mathrm{T}$ lymphocytes clearly outnumbered B lymphocytes in synovial fluid as defined by anti-T11 and pan-B monoclonal antibodies applied in an immunoperoxidase staining procedure.

Some monocytes and B lymphocytes display Ia, which is not present on resting T lymphocytes but is acquired by these cells upon activation. ${ }^{21} \mathrm{Ia}$ is therefore a useful activation marker for $\mathrm{T}$ lymphocytes. The added proportion of monocytes and $B$ lymphocytes was clearly lower than the total proportion of $\mathrm{Ia}^{+}$synovial fluid mononuclear cells, and it can be concluded that many of the synovial fluid $\mathrm{T}$ cells are activated in Reiter's syndrome. Furthermore, suppressor/cytotoxic $\mathrm{T}$ cells displaying $\mathrm{T} 8$ differentiation marker predominate in the synovial fluid in most effusions from chronic inflammatory arthritis. Surprisingly, in Reiter's syndrome inducer/ helper $\mathrm{T}$ cells displaying $\mathrm{T} 4$ differentiation marker outnumbered $\mathrm{T}^{+}$cells. This contrasts with the findings observed in chronic RA, where $\mathrm{T}^{+}$cells predominate in the joint effusion. High T4:T8 ratios in synovial fluid have been described in arthritis of less than one month's duration, whereas in chronic arthritis the T4:T8 ratio in synovial fluid was $1 \cdot 1 .^{22}$ However, the high T4:T8 ratio in our patients with Reiter's syndrome is hardly due to the acute nature of their synovitis, because the mean duration of the disease at the time of synovial fluid analysis was 11.6 months and within the Reiter's syndrome the duration of the disease did not correlate with the T4:T8 ratio. Instead, our findings suggest an active role for $\mathrm{T}^{+}{ }^{+}$inducer/helper cells in Reiter's syndrome and differences in the local pathogenetic mechanisms between rheumatoid arthritis and Reiter's syndrome.

This study was supported by the Finnish Foundation for Rheumatic Diseases, Finska Läkaresällskapet, Finnish Academy of Sciences, Helsinki University, Paulo Foundation, and Hoechst Fennica.

\section{References}

1 Wright V. Reiter's disease. In: Scott J T, ed. Copeman's textbook of the rheumatic diseases. Edinburgh: Churchill Livingstone, 1978: 549-66.

2 Willkens R F, Arnett F C, Bitter T, et al. Reiter's syndrome. Evaluation of preliminary criteria for definite disease. Arthritis Rheum 1981; 24: 844-9.

3 Calin A. Reiter's syndrome. In: Kelley W W, Harris E D Jr, Ruddy S, Sledge C B, eds. Textbook of rheumatology. Philadelphia: Saunders, 1981: 1033-46.

4 Brewerton D A, Caffrey M, Nicholls A, Walters D, Oates J K, James D C O. Reiter's disease and HL-A 27. Lancet 1973; ii: 996-8.

5 Aho K, Ahvonen P, Lassus A, Sievers K, Tiilikainen A. HL-A 27 in reactive arthritis. A study of yersinia arthritis and Reiter's disease. Arthritis Rheum 1974; 17: 521-5.

6 Dumonde D C. Arthritis associated with infection. Scand J Rheumatol 1975; 12(suppl): 115.

7 Ahlqvist J, Ahvonen P, Räsänen J, Wallgren G. Enteric infection with Yersinia enterocolitica. Large pyroninophilic cell 
reaction in mesenteric lymph nodes associated with early production of specific antibodies. Acta Pathol Microbiol Immunol Scand $[A]$ 1971; 79: 109-22.

8 Aho K. Pathogenesis of Reiter's syndrome and reactive arthritis. Scand J Rheumatol 1984; 52(suppl): 30-6.

9 Granfors K, Viljanen M. Tiilikainen A, Toivanen A. Persistence of $\operatorname{IgM}, \operatorname{IgG}$ and $\operatorname{IgA}$ antibodies to yersinia in yersinia arthritis. J Infect Dis 1980; 141: 424-9.

10 Leino R, Vuento R, Koskimies S, Viander M, Toivanen A. Depressed lymphocyte transformation by yersinia and Escherichia coli in yersinia arthritis. Ann Rheum Dis 1983; 42: 176-81.

11 Vuento R, Eskola J, Leino R, Koskimies S, Viander M. IgM, $\mathrm{IgG}$, and IgA synthesis in vitro in persons suffering from yersinia arthritis and in patients with ankylosing spondylitis. Ann Rheum Dis 1984; 43: 186-91.

12 Baldassare A R, Weiss T D, Tsai C C, Arthur R E, Moore T L, Zuckner J. Immunoprotein deposition in synovial tissue in Reiter's syndrome. Ann Rheum Dis 1981; 40: 281-5.

13 Ropes M W, Bennett G A, Cobb S, Jacox R, Jessar R A. 1958 revision of diagnostic criteria for rheumatoid arthritis. Bull Rheum Dis 1958; 9: 175-6.

14 Hsu S-M, Raine L. Fanger H. Use of avidin-biotin-peroxidase complex $(\mathrm{ABC})$ in immunoperoxidase techniques: a comparison between $\mathrm{ABC}$ and unlabeled antibody (PAP) procedures. $J$ Histochem Cytochem 1981; 29: 577-80.

15 Bergroth V, Konttinen Y T, Nykänen P, von Essen R, Koota
K. Proliferating cells in the synovial fluid in rheumatic discase: an analysis with autoradiography-imunoperoxidase double staining. Scand $J$ Immunol (in press).

16 Weinberger H W, Ropes M W, Kulka J P, Baucr W. Reiter`s $\overrightarrow{\overline{\vec{A}}}$ syndrome, clinical and pathological observations-a long termstudy of 16 cases. Medicine (Baltimore) 1962; 41: 35-91.

17 Konttinen Y T, Reitamo S, Ranki A, Häyry P, Kankaanpää U, Wegelius $O$. Characterization of the immunocompetent cells $\overline{\bar{\sigma}}$ of rheumatoid synovium from tissue sections and eluates. Arthritis Rheum 1981; 24: 71-9.

18 Konttinen Y T, Bergroth V, Nordström D, et al. Cellular immunohistopathology of acute, subacute and chronic synovitis in rheumatoid arthritis. Ann Rheum Dis 1985; 44: 549-55.

19 Wood D D, Ihrie E J, Dinarello C A, Cohen P L. Isolation of an interleukin-1 like factor from human joint effusions. Arthritis $\vec{\omega}$ Rheum 1983; 26: 975-83.

20 Nilsson E, Biberfeld G. T lymphocyte subpopulations defined by monoclonal antibodies in synovial fluid of patients with rheumatic disease. J Clin Lab Immunol 1982: 9: 93-7.

21 Reinherz E L, Kung P C. Pesando J M. Ritz J. Goldstein G, Schlossman S F. Ia determinants on human $T$ cell subsets $N$ defined by monoclonal antibody: activation stimuli required for of expression. J Exp Med 1979; 150: 1472-82.

22 Nilsson E, Biberfeld G. Synovial T lymphocytc subpopulations $\mathrm{O}$ in acute and chronic synovitis. Proceedings of the Xth European Congress of Rheumatology, Moscow, USSR, 1983: abstract 105. 